\title{
Vliv sedmidenního tréninkového kempu ve vyšší nadmořské výšce na vybrané funkční a biochemické parametry mladých běžců
}

\section{Impact of a seven-day training camp in the alpine environment on the selected functional and biochemical parameters of young runners}

\author{
Petr Bahenský', Jiří Suchý2 \\ 'Jihočeská univerzita, Pedagogická fakulta, České Budějovice \\ ${ }^{2}$ Univerzita Karlova, Fakulta tělesné výchovy a sportu, Praha
}

\begin{abstract}
Abstrakt
Cílem pilotní studie bylo ověřit vliv sedmidenního tréninkového kempu v nadmořské výšce 1880 metrů nad mořem na funkční a biochemické změny organismu mladých sportovců. Výzkum byl prováděn na $n=6$ (z toho 2 dívky), věk = 17,33 22,36, všichni patří mezi mládežnickou špičku v ČR. Sledovali jsme dynamiku změn ranní klidové srdeční frekvence, vybraných parametrů krevního obrazu (množství erytrocytů, hemoglobinu a hematokrit) a úroveň anaerobního prahu. Měření jsme prováděli 2 dny před odjezdem, 2 dny po návratu a 10 dnů po návratu z vyšší nadmořské výšky. Ranní klidovou srdeční frekvenci probandi měrili v průběhu 17 dnů před kempem a po dobu 14 dnů po návratu z kempu. $\checkmark$ rámci výzkumu bylo zjištěno: 10 dnů po návratu z kempu došlo ke snížení klidové srdeční frekvence naměřené před odjezdem o 2,44\% (v průběhu pobytu stoupla o 7,32 \%), množství erytrocytů stouplo o 1,2\%, hemoglobinu o 1,5\% a hematokritu o 1,6\%, u úrovně anaerobního prahu došlo ke zlepšení o 11 sekund (o 4,6\%). Týdenní pobyt je pravděpodobně príliš krátký, efekt zkráceného kempu nedosahuje účinku 21-28denního soustredění, presto je úroveň anaerobního prahu statisticky a věcně významná. Změna krevních hodnot není statisticky významná, věcná významnost vykazuje malý až střední efekt.
\end{abstract}

\begin{abstract}
The objective of the present thesis is to examine the effect of the seven-day training camp in the altitude of 1,880 meters above sea level on functional and biochemical changes of the organism of young sportspersons. The thesis is a pilot study. The research was conducted on $n=6$ (including 2 girls), age $=$ $17,33 \pm 2,36$, all of them belonging to the youth sports elite within the Czech Republic. We have observed the dynamics of changes of morning resting heart rate, selected parameters of blood count (amount of erythrocytes, haemoglobin and haematocrites) and level of the anaerobic threshold. The measurements were performed 2 days prior departure, 2 days after return and 10 days after return from the higher above-sea-level altitude. The morning resting heart rate was measured by the probands during the course of 17 days before the camp and during the course of 14 days after returning from the camp. In the scope of the research, we have arrived at the following results: the resting heart rate as measured before departure was reduced by $2.44 \% 10$ days after returning from the camp (it increased by $7.32 \%$ during the stay in the camp), the amount of erythrocytes increased by $1.2 \%$, that of haemoglobin increased by $1.5 \%$ and that of haematocrites increased by $1.6 \%$, level of the anaerobic threshold was improved by 11 seconds (by 4.6\%). Most probably, the weekly stay is too short; the effect of a shortened camp is not parallel to a training that lasts 21-28 days; however, the above change of level of the anaerobic threshold is statistically and substantively significant. Changes in blood values are not statistically significant, substantive significance shows a small to moderate effect.
\end{abstract}

Klíčová slova: vysokohorská príprava, krevní obraz, srdeční frekvence, laktát, sportovní trénink.

Key words: altitude training, blood count, heart rate, lactate, sports training. 
Výzkum byl podpořen z prostředků PRVOUK P38 a VZ MSM0021620864.

\section{ÚVOD}

Význam tréninku ve vyšší nadmořské výšce je zřejmý již velmi dlouho. Již v roce 1878 Francouz Bert (1878) poukazuje ve své práci na nepř́ijemnosti při pobytu ve vyšších nadmořských výškách způsobených nižším parciálním tlakem kyslíku. Od té doby jsou známy důvody zhoršené výkonnosti ve vyšší nadmořské výšce (Fibinger \& Novák, 1986). Zkoumání vlivu nadmořské výšky začalo v padesátých letech 20 . století, kdy bylo zjišsěno u obyvatel peruánských And určité přizpůsobení organismu na pobyt ve vyšší nadmořské výšce (Jokl, 1968). Systematický výzkum vlivu vyšší nadmořské výšky na organismus začal ale až v rámci př́ipravy na XIX. OH v Mexiku, které probíhaly v nadmořské výšce okolo 2200 m (Saunders, Pyne \& Gore, 2009; Vaněk, 1968). Efekt tréninku ve vyšší nadmořské výšce dokládají ve své práci i Bonetti \& Hopkins (2009), kteří ve své meta analýze studií $\mathrm{k}$ problematice tréninku ve vyšší nadmořské výšce za posledních 30 let zjistili, že špičkoví sportovci při pobytu i tréninku v přírodní vyšší nadmořské výšce zlepši svoji výkonnost o $5,2 \% \mathrm{v}$ porovnání s přípravou v nížině.

Pupiš \& Korčok (2007) dělí nadmořskou výšku následovně: nízká (do 1300 m n. m.), střední (1500-2500 m n. m.) a vysoká (nad 2500 m n. m.). Podle Dovalila (2005) se z hlediska sportovní výkonnosti a tréninku považuje za vyšší nadmořskou výšku 1500-3000 m n. m., vhodnou nadmořskou výškou pro př́ípravu sportovců je výška okolo $2000 \mathrm{~m} \mathrm{n}$. m.

Ve vyšší nadmořské výšce dochází v organismu k těmto změnám: prohloubené a zrychlené dýchání, zvýšení srdeční frekvence, zvýšení hodnot laktátu a snížení úrovně $\mathrm{VO}_{2 \max }$ (maximální spotřeby kyslíku). V důsledku adaptace v průběhu pobytu dochází v organismu ke snižení srdeční frekvence, zpomalení dýchání, zvýšení kapilarizace svalstva, zmnožení červených krvinek. Zmnožení červených krvinek může mít i negativní efekt - zahuštění krve. I proto je potřeba ve vyšších nadmořských výškách zvýšit přijem tekutin v porovnání s běžným pitným režimem v nížině (Gurský, 1988; Suchý, 2012). Klíčovou složkou výkonu (nejen) ve vytrvalostních disciplínách a to v nížině i ve vyšší nadmořské výšce je transport kyslíku k pracujícím svalům. Transport kyslíku zajištují červené krvinky pomocí hemoglobinu. Hematologické změny mohou značně zvýšit $\mathrm{VO}_{2 \max }$ organismu díky zlepšení kapacity krve pro přenos kyslíku k pracujícím svalům. Zvýšení počtu červených krvinek, koncentrace $\mathrm{Hb}$ (hemoglobinu) a $\mathrm{VO}_{2 \max }$ má pozitivní vliv také na aerobní výkon. Hlavním rysem dlouhodobého pobytu ve vyšší nadmořské výšce je nárůst transportní kapacity kyslíku v organismu. Z řady různých ukazatelů krevního obrazu je pro potřeby řízení tréninkového procesu ve vyšší nadmořské výšce vhodné sledovat především počet červených krvinek, hladinu hemoglobinu a hodnotu hematokritu (Suchý, 2012; Hochachka a kol., 1999). Anaerobní práh (ANP) je považováno v tréninkové praxi za indikátor speciálních vytrvalostních schopností sledovaných jedinců. U sportovně specifického zatížení při testování nacházíme těsnou vazbu mezi intenzitou zatížení na úrovni ANP a závodním výkonem. Invazivní stanovení ANP probíhá na základě změn koncentrace laktátu nebo parametrů acidobazické rovnováhy v krvi při stoupajícím zatížení (Bunc, 1989). Původní koncepce laktátového ANP stanovovala ANP pomocí koncentrace laktátu v krvi odpovídající koncentraci LA=4 mmol.1-1 (Mader \& Hollmann, 1977), tato hodnota se běžně použivá pro zjednodušení (Neumann, Pfützner \& Berbalk, 1998).

Co se týká délky pobytu ve vyšší nadmořské výšce, v současné době se, s ohledem na průběh aklimatizace, považují za optimální tréninkové kempy o délce 3-4 týdny (Levine \& Gundersen, 1997; Heinicke a kol. 2005). Tato doba je samozřejmě nezpochybnitelná, avšak ne vždy je možné tuto dobu dodržet, at již z důvodů organizačních, finančních či jiných. Zkráceným dvoutýdenním kempem ve vyšší nadmořské výšce se zabývali např. Svedenhag a kol. (1991). Suchý (2012) zkoumal význam zkráceného tréninkového kempu v délce trvání 10-12 dnů na vybrané fyziologické a biochemické parametry. Jeho studie potvrdila, že tréninkový kemp o délce 10 dnů má pozitivní vliv na vybrané ukazatele krevního obrazu a zvýšení kondičních předpokladů. Saunders, Pyne \& Gore (2009) doporučují pobyt ve vyšší nadmořské výšce nejméně 2 týdny pro zlepšení sou- 
těžního výkonu ve vyšší nadmořské výšce, 3-4 týdny pro zlepšení výkonnosti na úrovni hladiny moře. Někteř́i běžci v této výšce žijí celý život, jiní se do ní stěhují trvale (Suchý, 2012). Informací o tréninku mladých běžců ve vyšší nadmořské výšce se v literatuře objevuje velmi málo, tímto tématem se zabývá např. Buchheit a kol. (2012) nebo Saltin a kol. (1995) nebo Suchý (2012), který testoval mladé lyžaře $\mathrm{v}$ dorosteneckém a juniorském věku.

Aklimatizace ve vyšších nadmořských výškách u třítýdenního kempu je velice podrobně zpracována, má 3 fáze (Dovalil, 2005; Suchý a kol., 2009):

I. fáze: 1.-(4.) 6. den. Tato fáze je charakterizována sníženou intenzitou zatížení, energetickým krytím převážně aerobním.

II. fáze: (4.) 6.-(8) 12. den. V této fázi se zvyšuje zatížení v náročnějším aerobním režimu, dvoufázový až tříázový trénink. Ke konci je možný méně náročný laktátový trénink.

III. fáze: 12.-21. den. Lze postupně přecházet k obvyklému tréninku v nížině.

V dostupné literatuře jsme nenalezli žádnou zmínku o tom, zda i týdenní tréninkový kemp ve vyšší nadmořské výšce pozitivně ovlivní stav trénovanosti a vybrané krevní ukazatele u sledovaných vytrvalostních sportovců, pouze Ratz, Coggan \& McGregor (2009) zkoumali vliv týdenního spánku v simulované nadmořské výšce $2500 \mathrm{~m}$ na maximální výkon plavců a cyklistů, ale nezjistil žádné významné změny. Z fází aklimatizace vyplývá, že př̀i týdenním tréninkovém pobytu ve vyšší nadmořské výšce se sportovci dostanou pouze na pomezí I. a II. aklimatizační fáze. $Z$ toho důvodu lze na týdenním kempu praktikovat pouze aerobní tréninky v mírné intenzitě.

Co se týká samotného pobytu, někteří odborníci preferují bydlení nahoře a trénink dole („live high - train low“ - LHTL), někteři bydlet i trénovat nahoře, jiní zase bydlet dole a trénovat nahoře. Podle Levina \& Gundersena (1997) je velice efektivní varianta bydlet nahoře a trénovat dole. Rusko, Tikkanen \& Peltonen (2004) preferují variantu bydlet i trénovat nahoře, ale bydlení nahoře a trénink dole považují též za efektivní. Obě varianty při odborném vedení mají efekt, doporučují nejméně třitýdenní kemp alespoň ve výšce 2000 m n. m. Chapman, Gundersen \& Levine (1998) zjištovali individuální reakci na vyšší nadmořskou výšku. Zjistili, že u sportovců, kteří dobře reagují na vyšší nadmořskou výšku je největší efekt u varianty žít i trénovat nahoře. Pomocí přípravy před odjezdem na soustředění také umožnili minimalizovat počet atletů, kteří na vyšší nadmořskou výšku nereagovali pozitivně.

Dill a kol. (1974) také zjistili, že při 3týdenním tréninkovém kempu v nadmořské výšce $2300 \mathrm{~m}$ n. m. došlo k úbytku tělesné hmotnosti u sportovců o $2,1 \%$, z čehož $1 / 3$ připadala na tělesný tuk.

Výsledky této práce mohou být také využity jako praktická ukázka, jak sledovat vliv vyšší nadmořské výšky na sportovce $\mathrm{v}$ běžné tréninkové praxi.

\section{CÍL}

V literatuře je popsán jako ideální tří až čtyřtýdenní tréninkový pobyt ve vyšší nadmořské výšce a desetidenní pobyt jako limitní, co se týká funkčního a biochemického efektu. Také jsou popsány varianty zkráceného pobytu ve vyšší nadmořské výšce, ale nikoliv sedmidenní. Cílem této práce je ověřit, zda při týdenním tréninkovém kempu ve výšce $1880 \mathrm{~m} \mathrm{n}$. m. dojde ke změně funkčních a biochemických parametrů organismu mladých sportovců. Sledovali jsme dynamiku změn vybraných krevních parametrů (erytrocyty, hemoglobin a hematokrit), anaerobního prahu, ranní srdeční frekvence.

\section{METODIKA}

Pro ověření stanovených cílů byly použity následující metody:

1. Měření ranní klidové srdeční frekvence $(\mathrm{SF})$ - probandi měřili a zaznamenávali 17 dnů před soustř̌eděním, v průběhu soustř̌edění a po dobu 2 týdnů po soustř̌edění ranní srdeční frekvenci 
pomocí sporttesterů (Polar 3000, Finsko). Metodika měření: po probuzení si sportovci sami nasadili sporttester a zaznamenali nejnižší SF v prüběhu 3 minut.

2. Vybrané parametry krevního obrazu - 4. den před soustředěním, 1. den po návratu a 10. den po návratu jsme u všech sledovaných provedli rozbor krve na stanovení množství:

- hemoglobinu [g. $\left.1^{-1}\right]$

- hematokrit [poměr erytrocytů k objemu krve ve zkoumaném vzorku]

- počet erytrocytů [tera..$\left.^{-1}\right]$

Odběry byly realizovány vždy ve stejnou dobu spolupracující sportovní lékařkou v akreditované biochemické a hematologické laboratoři na Poliklinice Jih v Českých Budějovicích.

3. Dynamika změn anaerobního prahu - byl opakovaně proveden test $4 \times 1600 \mathrm{~m}$ na silnici s pauzou 2 minuty s měřením laktátu pomocí prístroje accutrend firmy Roche (Německo), u nějž výrobce udává možnou chybu měření $3 \%$. Rychlosti běhu byly stanoveny takto: 1 . úsek pod aerobním prahem (AEP), 2. úsek těsně nad aerobním prahem, 3. úsek mezi aerobním a anaerobním prahem a 4. úsek rychleji, než anaerobní práh. Aerobní a anaerobní práh byly stanoveny na základě stupňovaného zátěžového testu uskutečněného před pobytem ve výšce. Zjištěné hodnoty jsme zanesli do grafu a pro zjednodušení jsme odečetli rychlost na úrovni 2 a 4 mmol.1-1 . Laktátové testy na soustředění byly realizovány v nadmořské výšce $1800 \mathrm{~m}$. Všechna měření před a po soustř̌edění byla absolvována v nadmořské výšce $400 \mathrm{~m}$.

\section{Matematické a statistické metody}

Pro posouzení věcné významnosti rozdílů sledovaných veličin pomocí Cohenova koeficientu d. Hendl (2004) doporučuje toto hodnocení, které při hodnocení změn v rámci našeho výzkumu sledovaných ukazatelů používáme:

- $\mathrm{d}>0,8$ vyjadřuje velký účinek

- hodnota d v intervalu 0,5 - 0,8 vyjadřuje středně velký účinek

- hodnota d v intervalu 0,2 - 0,5 vyjadřuje malý účinek

- $\mathrm{d}<0,2$ vypovídá o slabém účinku

Též jsme zjištovali statistickou významnost rozdílu středních hodnot sledovaných veličin pomocí parametrického párového t-testu pro dva závislé výběry. $\mathrm{S}$ ohledem na charakter výzkumu jsme se rozhodli posuzovat statistickou významnost rozdílů na hladině významnosti $(p)<0,05$. Tento nástroj jsme použili, přestože si uvědomujeme, že velikost sledovaného souboru je limitní.

\section{Charakteristika probandi̊}

V tabulce 1 je uvedena aktuální výkonnostní úroveň probandů 3 měsíce po soustředění.

Tabulka 1: Nejlepší výkon probandů v období 3 měsíců po soustředění ve vyšší nadmořské výšce

Muži:

\begin{tabular}{|c|c|c|c|}
\hline proband & věk & trat' & výkon \\
\hline D. K. & 16 let & $1500 \mathrm{~m}$ & $4: 13,23$ \\
\hline J. M. & 20 let & $800 \mathrm{~m}$ & $1: 54,52$ \\
\hline J. P. & 15 let & $1500 \mathrm{~m}$ & $4: 36,85$ \\
\hline D. V. & 21 let & $3000 \mathrm{~m}$ & $9: 10,47$ \\
\hline
\end{tabular}

Ženy:
\begin{tabular}{|c|c|c|c|}
\hline proband & věk & trat' & rýkon \\
\hline A. F. & 17 let & $1500 \mathrm{~m}$ & $4: 49,93$ \\
\hline L. V. & 15 let & $800 \mathrm{~m}$ & $2: 18,69$ \\
\hline
\end{tabular}

Zkoumali jsme 4 běžce a 2 běžkyně na stř̌ední a dlouhé tratě ve věku 15-21 let, věk=17,33 $\pm 2,36$. Námi sledovaný soubor není rozsáhlý ani homogenní, ale jedná se o pilotní studii. Čtyři ze sledovaných probandů získali medaile na mládežnických MČR, další dva dosáhli účasti ve finále na MČR. Všichni běžci se zúčastnili týdenního soustředění v údolí Vallelunga (Itálie) v termínu 14.-21. 4. 2013, kde bydleli ve výšce 1880 metrů nad mořem. Ani jeden z účastníků výzkumu neměl 
doposud zkušenost s tréninkovým pobytem ve vyšší nadmořské výšce. $V$ tabulce 2 je tréninkový plán po dobu trvání výzkumu.

Tabulka 2: Trénink absolvovaný 7.-28. 4. 2013

\begin{tabular}{|c|c|}
\hline 7. 4. & volno \\
\hline 8. 4. & $\begin{array}{l}\text { dopoledne: běh nízkou intenzitou } 6 \mathrm{~km}, \mathrm{R} \text { (rovinky) } 5 \times 100 \mathrm{~m} \text {, } \\
\text { odpoledne: } 3 \times 4 \times 150 \mathrm{~m} \text { v tempu } 800 \mathrm{~m}\end{array}$ \\
\hline 9. 4. & $\begin{array}{l}\text { dopoledne: } 6 \times 1 \mathrm{~km} \text { P 3' (pauza } 3 \text { minuty) v tempu } 10000 \mathrm{~m} \text {, odpoledne: } \\
\text { běh nízkou intenzitou } 6 \mathrm{~km} \text {, R } 5 \times 100 \mathrm{~m}\end{array}$ \\
\hline 10.4. & dopoledne: plavání $1 \mathrm{~km}$, běh nízkou intenzitou $6 \mathrm{~km}$, odpoledne: $4 \times 2 \mathrm{~km}$ na úrovni AEP \\
\hline 11. 4. & dopoledne: laktátový test, odpoledne: kruhový trénink 40’ \\
\hline 12. 4. & dopoledne: vybíhané kopce $10 \times 200 \mathrm{~m}$, odpoledne: běh nízkou intenzitou $6 \mathrm{~km}$, R $5 \times 100 \mathrm{~m}$ \\
\hline 13. 4. & běh nízkou intenzitou $10 \mathrm{~km}, \mathrm{R} 5 \times 100 \mathrm{~m}$ \\
\hline 14. 4. & př́ijezd, běžky 7-10 km, běh nízkou intenzitou $4 \mathrm{~km}$ \\
\hline 15.4. & dopoledne: běžky 7-12 km, odpoledne: turistika 2:30 hod (převýšení $650 \mathrm{~m}$ ) \\
\hline 16. 4. & dopoledne: laktátový test, odpoledne: běh nízkou intenzitou 8-12 km, R 5×100 m \\
\hline 17. 4. & dopoledne: $2 \times 4 \times 300 \mathrm{~m}$ v tempu $1500 \mathrm{~m}$, odpoledne: turistika 2 hod (převýšení $500 \mathrm{~m}$ ) \\
\hline 18. 4. & dopoledne: běžky 7-12 km, odpoledne: $2-4 \times 2$ km rychlostí na AEP pauza 2 minuty \\
\hline 19. 4. & $\begin{array}{l}\text { dopoledne: } 2 \times 4 \times 200 \mathrm{~m} \text { v tempu } 800 \mathrm{~m} \text {, odpoledne lehký běh nízkou intenzitou 6-8 km, } \\
\text { R } 5 \times 100 \mathrm{~m}\end{array}$ \\
\hline 20.4. & dopoledne: laktátový test, odpoledne: lehký běh nízkou intenzitou 6-8 km, R 5×100 m \\
\hline 21.4. & ráno: běh nízkou intenzitou $6-8 \mathrm{~km}, \mathrm{R} 5 \times 100 \mathrm{~m}$, odjezd \\
\hline 22.4. & volno \\
\hline 23.4. & dopoledne: laktátový test, odpoledne: běh nízkou intenzitou $6 \mathrm{~km}, \mathrm{R} 5 \times 100 \mathrm{~m}$ \\
\hline 24. 4. & dopoledne: běh nízkou intenzitou 8 km, R 5×100 m, odpoledne: posilování \\
\hline 25.4. & $2 \times 5 \times 300 \mathrm{~m}$ v tempu $1500 \mathrm{~m}$ \\
\hline 26.4. & dopoledne: $3 \times 2 \mathrm{~km}$ na úrovni AEP, odpoledne: běh nízkou intenzitou $6 \mathrm{~km}, \mathrm{R} 5 \times 100 \mathrm{~m}$ \\
\hline 27. 4. & běh nízkou intenzitou $12 \mathrm{~km}, \mathrm{R} 5 \times 100 \mathrm{~m}$ \\
\hline 28.4. & dopoledne: vybíhané kopce $10 \times 150 \mathrm{~m}$, odpoledne: běh nízkou intenzitou $6 \mathrm{~km}$, R $5 \times 100 \mathrm{~m}$ \\
\hline
\end{tabular}

Trénink na běžkách byl absolvován nízkou intenzitou. Rychlost běhu nízkou intenzitou je stanovena o cca 40-50 sekund pomaleji, než je rychlost běhu na úrovni AEP. Rychlost úseků je u každého probanda rozdílná, vychází z individuální výkonnostní úrovně.

První dva dny soustředění probandi absolvovali pouze běh nízkou intenzitou, turistiku a rovinky, postupně byly zařazovány tréninky o větší intenzitě i objemu. Oproti tréninku před kempem došlo k navýšení času zatížení v průměru o $26 \%$ z 11:15 hod na 15:15 hod za mikrocyklus. Změnou v obsahu tréninku na soustředění bylo zařazení 2 tréninkových jednotek vysokohorské turistiky, první v délce trvání 2:30 hod s převýšením $650 \mathrm{~m}$, druhý 2:00 hod dlouhý s převýšením $500 \mathrm{~m}$.

Hmotnost probandů jsme měřili 6 dnů před odjezdem, 1. a 6 . den soustředění, 1. a 8 . den po návratu ze soustředění. Též jsme měřili hodnotu tělesného tuku bioimpedancí dle Bunce (2006), srovnatelné výsledky vyšly i při měření kaliperem.

Provedený výzkum byl prováděn se souhlasem Etické komise UK FTVS, č. j.: 0149/2013. Rodiče všech účastníků signovali informovaný souhlas. 


\section{VÝSLEDKY}

Tabulka 3: Změny hmotnosti (kemp 14.-21. 4.)

\begin{tabular}{|l|c|c|c|c|c|}
\cline { 2 - 6 } \multicolumn{1}{c|}{} & $\mathbf{8 . 4 . 2 0 1 3}$ & $\mathbf{1 4 . 4 . 2 0 1 3}$ & $\mathbf{1 9 . 4 . 2 0 1 3}$ & $\mathbf{2 2 . 4 . 2 0 1 3}$ & $\mathbf{2 9 . 4 . 2 0 1 3}$ \\
\hline hmotnost [kg] & 64,7 & 64,5 & 64,4 & 64,1 & 64,3 \\
\hline směr. odchylka & 10,3 & 10,0 & 10,1 & 10,2 & 10,1 \\
\hline prům. odchylka & 8,1 & 7,7 & 8,1 & 8,2 & 7,9 \\
\hline
\end{tabular}

U sledovaných sportovců jsme naměřili v průběhu kempu pokles hmotnosti o 1\% (tabulka 3) a pokles množství tuku z $15,78 \%$ na $13,83 \%$, tj. o $14,1 \%$, měřeno těsně před soustředěním a dva dny po soustředění. V následujících osmi dnech došlo opět k navýšení hodnot. Hmotnost byla měřena pokaždé ve stejnou dobu před tréninkem za předpokladu srovnatelného zavodnění a vyměšování.

Z tabulek 4 a 5 vyplývá, že naměřená změna hmotnosti a množství tuku v těle před a po kempu je statisticky významná, věcná významnost vykazuje slabý efekt.

Tabulka 4: Porovnání hmotnosti a množství tuku pomocí t-testu

\begin{tabular}{|l|c|c|}
\cline { 2 - 3 } \multicolumn{1}{c|}{} & hmotnost & tuk \\
\hline 8. 4. vs. 22. 4. & 0,0131 & 0,0500 \\
\hline 8. 4. vs. 29. 4. & 0,0500 & 0,0005 \\
\hline
\end{tabular}

Tabulka 5: Porovnání hmotnosti a množství tuku pomocí Cohenova d

\begin{tabular}{|l|c|c|}
\cline { 2 - 3 } \multicolumn{1}{c|}{} & hmotnost & tuk \\
\hline 8.4. vs. 22.4. & 0,063 & 0,189 \\
\hline 8.4. vs. 29.4. & 0,041 & 0,185 \\
\hline
\end{tabular}

Během týdenního pobytu absolvovali dva tréninky na stadionu v $1000 \mathrm{~m}$ n. m., (jeden trénink tempové rychlosti a jeden trénink speciálního tempa, oba v krátkých úsecích, snížený objem), dva tréninky ve výšce $1500 \mathrm{~m}$ n. m. (jeden klus a jeden trénink na rozvoj AEP), 2 odpoledne se věnovali pěšímu výstupu do výšky $2450 \mathrm{~m} \mathrm{n}$. m. a zbývajících 8 tréninků proběhlo v místě ubytování v nadmořské výšce $1800-1950 \mathrm{~m} \mathrm{n}$. m. (většinou běh na běžkách, klusy, rovinky + laktátové testy).

Klidovou srdeční frekvenci jsme měřili 17 dnů před soustředěním, 7 dnů na soustředění ve vyšší nadmořské výšce a 14 dnů po soustř̌edění (tabulka 6).

Tabulka 6: Klidová srdeční frekvence

\begin{tabular}{|l|c|c|c|}
\cline { 2 - 4 } \multicolumn{1}{c|}{} & nížina před soustreděním & soustředění - výška & nížina po soustředění \\
\hline počet dnů & 17 & 7 & 14 \\
\hline průměr & 46,6 & 50,3 & 45,8 \\
\hline směr. odchylka & 3,2 & 2,9 & 3,3 \\
\hline průměr odchylka & 2,3 & 2,3 & 2,5 \\
\hline
\end{tabular}

V průběhu pobytu ve výšce stoupla ranní SF o 7,32\% oproti naměřeným hodnotám před tréninkovým kempem. Tento nárůst je statisticky $(\mathrm{p}<0,05)$ i věcně významný (velký účinek). Po návratu klesla SF o 2,44 \% oproti SF před soustředěním. Změna srdeční frekvence po soustředění oproti SF před soustředěním není statisticky významná $(p>0,05)$, věcná významnost vykazuje malý efekt, viz tabulka 7. Pokles hodnot SF naměřených po návratu ze soustředění oproti hodnotám v průběhu soustř̌edění o 9,9\% je statisticky ( $p>0,05$ ) a věcně významný (velký účinek). 
Tabulka 7: Věcná a statistická významnost dynamiky ranní srdeční frekvence

\begin{tabular}{|l|c|c|c|}
\cline { 2 - 4 } \multicolumn{1}{c|}{} & $\begin{array}{c}\text { 17 dnů před kempem } \\
\text { vs. 7 dnů na kempu }\end{array}$ & $\begin{array}{c}\text { 7 dnů na kempu } \\
\text { vs. 14 dnů po kempu }\end{array}$ & $\begin{array}{c}\mathbf{1 7} \text { dnů před kempem } \\
\text { vs. 14 dnü po kempu }\end{array}$ \\
\hline t- test & 0,00471 & 0,00693 & 0,1438 \\
\hline Cohenovo d & 1,201 & 1,482 & 0,266 \\
\hline
\end{tabular}

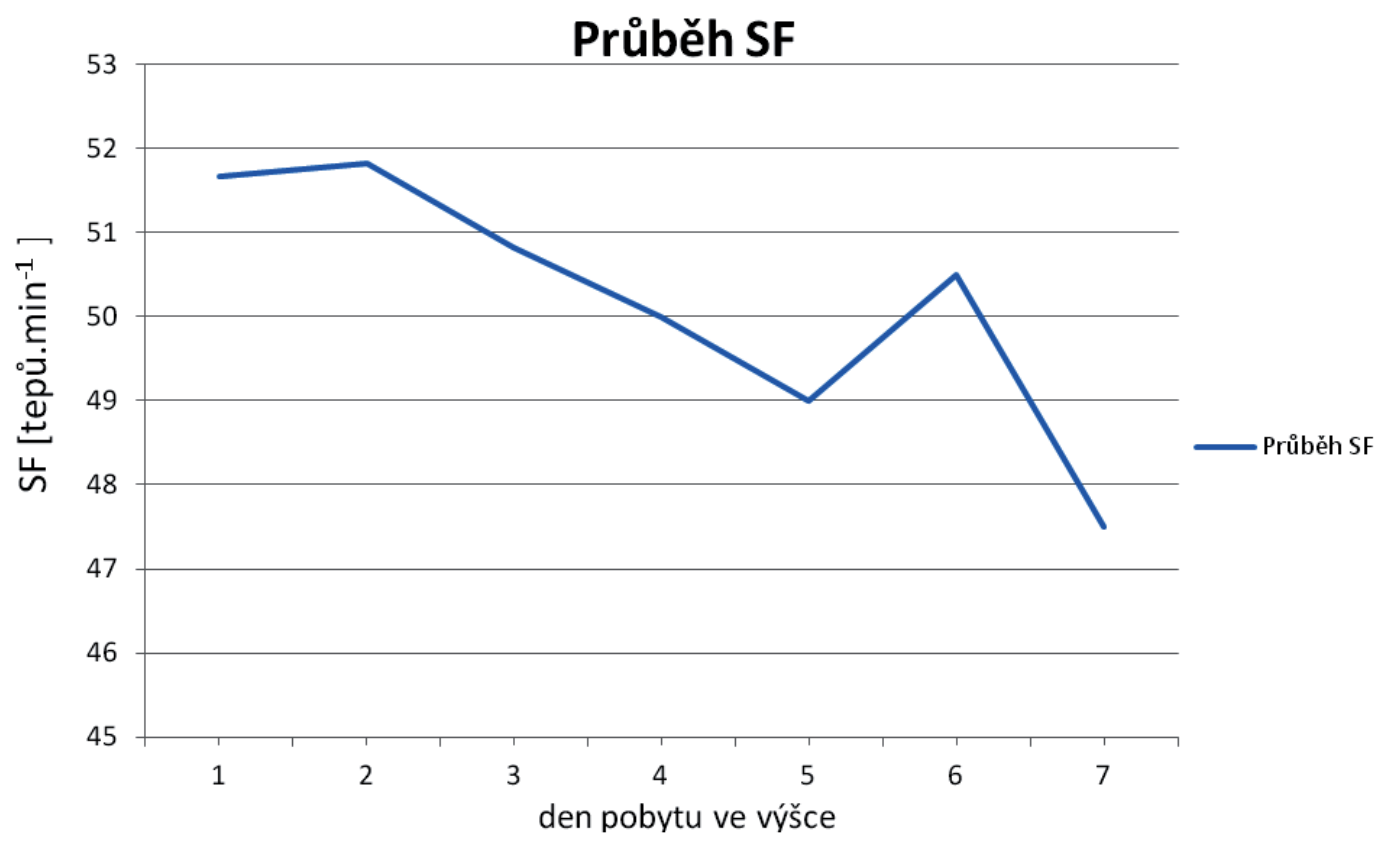

Graf 1: Průběh klidové SF - průměr SF [tepů.min ${ }^{-1}$ ] v průběhu soustředění

Na soustředění je znatelný postupný pokles ranní SF (po nárůstu ihned po př́ijezdu). Šestý den SF vzrostla, pravděpodobně i v důsledku náročnějšího tréninku den předtím (graf 1 ).

Tabulka 8: Krevní testy (kemp 14.-21. 4.)

\begin{tabular}{|l|c|c|c|c|c|c|c|c|c|}
\cline { 2 - 10 } \multicolumn{1}{c|}{} & \multicolumn{3}{c|}{ erytrocyty } & \multicolumn{3}{c|}{ hemoglobin } & \multicolumn{3}{c|}{ hematokrit } \\
\cline { 2 - 10 } \multicolumn{1}{c|}{} & $\mathbf{9 . 4 .}$ & $\mathbf{2 2 . 4 .}$ & $\mathbf{3 0 . 4}$ & $\mathbf{9 . 4 .}$ & $\mathbf{2 2 . 4 .}$ & $\mathbf{3 0 . 4}$ & $\mathbf{9 . 4 .}$ & $\mathbf{2 2 . 4 .}$ & $\mathbf{3 0 . 4}$. \\
\hline průměr & 5,02 & 5,02 & 5,08 & 148,5 & 148,5 & 150,7 & 0,433 & 0,435 & 0,44 \\
\hline směr. odchylka & 0,27 & 0,24 & 0,33 & 7,09 & 6,45 & 8,32 & 0,011 & 0,009 & 0,18 \\
\hline prům. odchylka & 0,25 & 0,21 & 0,28 & 6,5 & 5,83 & 7,33 & 0,01 & 0,008 & 0,17 \\
\hline
\end{tabular}

V tabulce 8 jsou uvedeny průměrné hodnoty krevních testů, množství erytrocytů bylo 10 dnů po soustředění o 1,2 \% vyšší oproti vzorku před soustředěním. U hemoglobinu byl nárůst o $1,5 \%$ a u hematokritu o 1,6\%. Nárůst krevních hodnot není statisticky významný ( $p>0,05)$, u hodnot erytrocytů a hemoglobinu vykazuje věcná významnost malý efekt, u hematokritu malý až střední efekt, viz tabulky 9 a 10. 
Tabulka 9: T-test porovnání krevních testů (kemp 14.-21. 4.).

\begin{tabular}{|l|c|c|c|}
\cline { 2 - 4 } \multicolumn{1}{c|}{} & erytrocyty & hemoglobin & hematokrit \\
\hline 9. 4. vs. 22. 4. & 1 & 1 & 0,363 \\
\hline 22. 4. vs. 30. 4. & 0,317 & 0,189 & 0,415 \\
\hline 9. 4. vs. 30.4. & 0,237 & 0,137 & 0,175 \\
\hline
\end{tabular}

Tabulka 10. Porovnání krevních testů - Cohenovo d (kemp 14.-21. 4.)

\begin{tabular}{|l|c|c|c|}
\cline { 2 - 4 } \multicolumn{1}{c|}{} & erytrocyty & hemoglobin & hematokrit \\
\hline 9. 4. vs. 22. 4. & 0 & 0 & 0,199 \\
\hline 22. 4. vs. 30. 4. & 0,208 & 0,296 & 0,351 \\
\hline 9. 4. vs 30.4. & 0,199 & 0,285 & 0,469 \\
\hline
\end{tabular}

V grafu 2 je vyznačena změna úrovně anaerobního prahu. Na počátku kempu jeho hodnota klesla o 8 sekund, postupně se, díky adaptaci, zlepšovala. 2 dny po návratu byla úroveñ již o 1 sekundu lepší, než před odjezdem a 10 dnů po návratu byla hodnota anaerobního prahu o 11 sekund lepší, než před odjezdem na soustředění, což představuje posun o 4,6 \%. Změna byla statisticky významná ( $\mathrm{p}<0,05)$, věcná významnost vykazuje malý až střední efekt, viz tabulka 11.

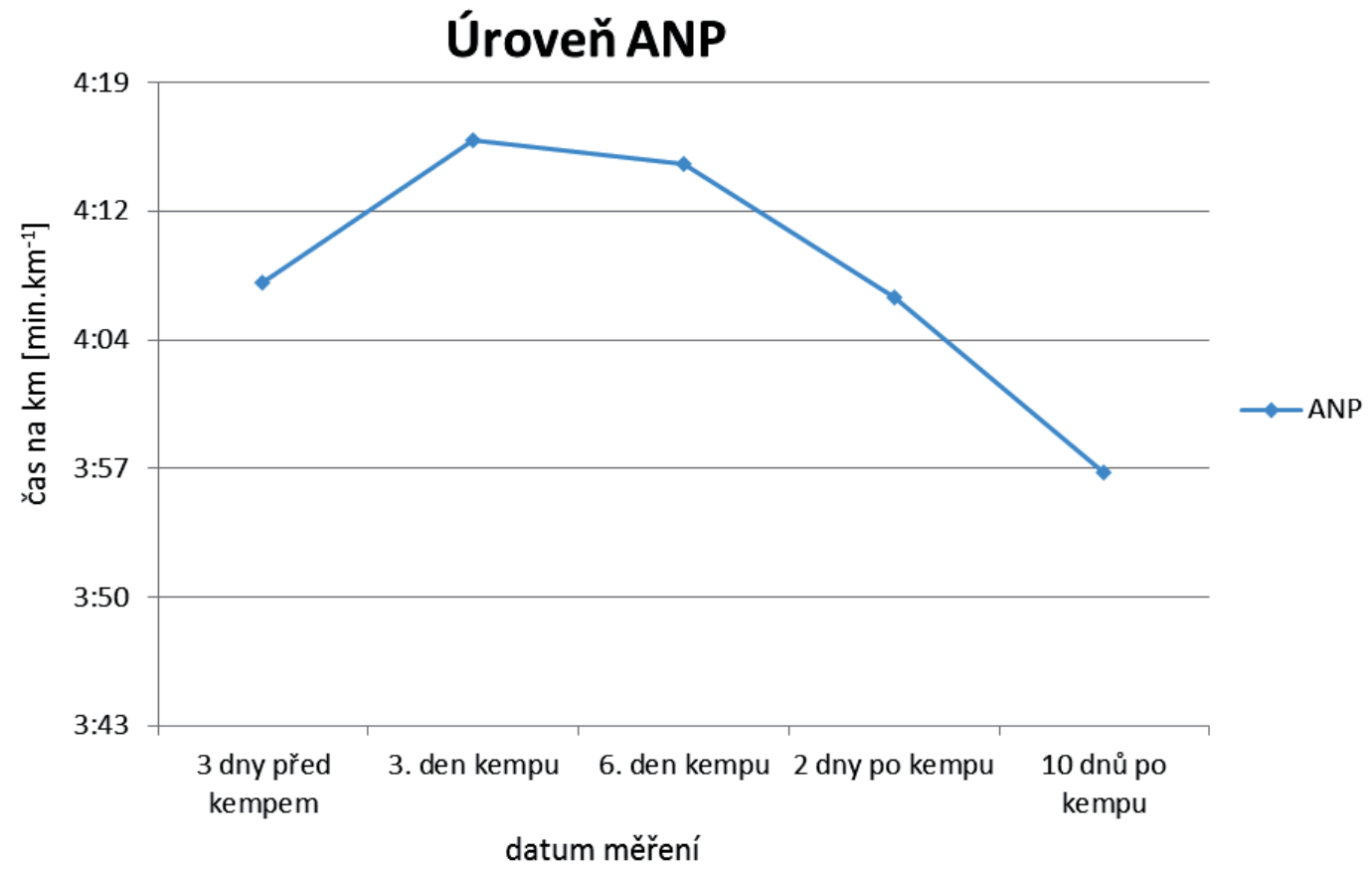

Graf 2: Změna úrovně anaerobního prahu

Tabulka 11. Změna úrovně ANP (kemp 14.-21. 4.)

\begin{tabular}{|l|c|c|c|c|c|}
\cline { 2 - 6 } \multicolumn{1}{c|}{} & 9. 4. vs. 30. 4. & 9. 4. vs. 16. 4. & 9. 4. vs. 19. 4. & 9. 4. vs. 23. 4. & 23. 4. vs. 30. 4. \\
\hline t-test & 0,0185 & 0,0084 & 0,0452 & 0,6007 & 0,0286 \\
\hline Cohenovo d & 0,451 & 0,377 & 0,338 & 0,388 & 0,411 \\
\hline
\end{tabular}




\section{DISKUSE}

Vysokohorským tréninkem se zabývá mnoho autorů, jeho vliv na organismus sportovců je popsán. Jen zlomek publikací se ale týká vlivu na organismus mladých běžců. Potvrdilo se, že týdenní tréninkový kemp ve vyšší nadmořské výšce nemůže nahradit tréninkový pobyt o délce 21-28 dnů. Daniels \& Oldridge (1970) prokázali při opakovaných třítýdenních pobytech ve vyšší nadmořské výšce navýšení množství hemoglobinu o $6 \%$, Berglund a kol. (2002) o $9 \%$, Heinicke a kol. (2005) o 8,5\%. Suchý (2012) udává po absolvování desetidenním pobytu ve vyšší nadmořské výšce zvýšení hemoglobinu o 4,2\%. K těmto hodnotám se sledovaní běžci po týdenní intervenci nepřibližili. To potvrzuje, že za jeden týden nedošlo k plné aklimatizaci běžců. Přesto i po týdenní intervenci došlo ke zvýšení krevních hodnot.

Námi naměřená dynamika ranní SF také odpovídá zjištěným poznatkům. Došlo k menšímu poklesu ranní SF, než je popisováno u 3-4 týdenní intervence.

V literatuře jsou zmínky o individuálně odlišné hranici ANP. My jsme, pro zjednodušení, porovnávali dynamiku změn rychlostí na úrovni $4 \mathrm{mmol}^{-1} \mathrm{l}^{-1}$. Dynamika úrovně ANP dosáhla na tak krátký pobyt ve vysokohorském prostředí neobvyklých změn. Zlepšení hodnoty ANP nekoresponduje se zlepšením biochemických ukazatelů. Domníváme se, že určitý podíl na tomto zlepšení může mít i silová intervence $\mathrm{v}$ průběhu pobytu a následný transfer do ekonomiky a rychlosti pohybu, což je pro nás námět na další šetření.

Plánovali jsme porovnat i dynamiku změn rychlosti běhu na úrovni aerobního prahu, ale při stanovení intenzit zatížení ve vyšší nadmořské výšce došlo ke špatnému odhadu reakce u některých probandů. $\mathrm{V}$ jeho důsledku nebylo možné hodnotu $2 \mathrm{mmol.1^{-1 }}$ stanovit $\mathrm{z}$ naměřených výsledků.

$\mathrm{V}$ průběhu měření ranní SF nebyl u probandů nikdo z řešitelů fyzicky přítomen, ale všichni účastníci výzkumu byli patřičně poučeni o postupu měření ranní SF a měřili každý den stejným způsobem. Naměřené hodnoty ranní SF po návratu ze soustředění mohly být u 2 účastníků mírně ovlivněné lehkým nachlazením jednoho a lehkou alergickou reakcí na pyly u druhého. Uvažujeme o dalším výzkumu, rádi bychom provedli porovnání s kempem v nížině.

Je nám známo, že 6 probandů není rozsáhlý soubor, ale jedná se o pilotní studii, a provedli jsme výběr nejlepších atletů. Výběr byl proveden ze 2 důvodů:

1. jedná se o finančně náročný výzkum

2. vysokohorský trénink využívají vrcholoví sportovci, sportovci nižší úrovně mohou využít jiné možnosti př́ipravy, ne tak finančně náročné

Z organizačních důvodů jsme neměli k dispozici data od kontrolní skupiny probandů, která pobyt ve vyšší nadmořské výšce neabsolvovala.

Cesta na soustředění a zpět trvá 6:30 hod, předpokládáme tedy, že by nemělo dojít k ovlivnění výsledků testů den po návratu.

\section{ZÁVĚR}

Aktivace srdečně cévního systému při týdenním pobytu ve vyšší nadmořské výšce není srovnatelná s doporučovanou dobou pobytu, ale v kombinaci s optimálním zatížením a vhodně zvolenou skladbou může i týdenní tréninkový kemp ve výšce $1880 \mathrm{~m}$ n. m. podpořit výkonnost běžců na střední a dlouhé tratě, především v kvalitativním posunu rychlosti běhu na úrovni anaerobního prahu. V důsledku týdenního soustředění v nadmořské výšce $1880 \mathrm{~m}$ došlo ke statisticky, ale ne věcně významnému zvýšení množství erytrocytů o $1,2 \%$, hemoglobinu o $1,5 \%$ a hematokritu o 1,6\%. Oproti krevním ukazatelům se úroveň ANP zvýšila statisticky i věcně významně (zlepšení o 4,6\%) a blíží se hodnotám uváděným v literatuře popisující zlepšení výkonnosti v důsledku absolvování 3týdenního tréninkového kempu ve vyšší nadmořské výšce. Klidová SF se po kempu snížila o 2,44 \% oproti hodnotám před intervencí. Toto zvýšení není statisticky ani věcně významné. Doporučit předložený model soustředění lze opravdu jen v situaci, kdy delší pobyt není 
možný. Po týdnu pobytu ve vyšší nadmořské výšce je sice organismus již zčásti adaptovaný, ale každým dalším dnem pobytu dochází ke zlepšování biochemických i fyziologických ukazatelů, které po týdnu nejsou na požadované úrovni.

\section{Literatura}

Berglund, B., Gennser, M., Örnhagen, H., Östberg, C. \& Wide, L. (2002). Erythropoietin concentrations during 10 days of normobaric hypoxia under controlled environmental circumstances. Acta Physiol Scand, 174, 225-229.

Bert, P. (1878). La pression baramétrique, recherches de physiologie experimentace.Paris: Librairecde L'Academie de Medecine.

Bonetti, D. L. \& Hopkins, W. G. (2009). Meta-analysis of sea level performance following adaptation to hypoxia. Sports Medicine 39, s. 107-127.

Buchheit, M., Kuitunen, S., Voss, S. C., Williams, B., Mendez-Villanueva, A. \& Bourdon, P. C. (2012). Physiological strain associated with high-intensity hypoxic intervals in highly trained young runners. Journal of Strength \& Conditioning Research. 26 (1), 94-106.

Bunc, V. (1989). Biokybernetický prístup k hodnocení reakce organismu na tělesné zatižení. Praha: VúT UK.

Bunc, V. (2006). Body composition as a determining factor in the aerobic fitness and physical performance of Czech children. Acta Univ. Palacki. Olomuc., 36 (4), 39-45.

Daniels, J. \& Oldridge, N. (1970). The effects of alternate exposure t o altitude and sea level on world-class middle-distance runners. Medicine Science in Sports 2, 107-112.

Dill, D. B., Braithwaite, K., Adams, W. C. \& Bernauer, E. M. (1974). Blood volume of middle distance runners: effect of 2,300 m altitude and comparison with nonathletes. Medicine and Science in Sports and Exercise 6 (1), 1-7.

Dovalil, J. et al. (2005). Výkon a trénink ve sportu. Praha: Olympia.

Fibinger, I. \& Novák, J. (1986). Hypoxie jako tréninkový prostředek ve sportovní prípravě. Praha: ÚV ČSTV.

Gurský, K. (1988). Človek vo velhorských podmienkach. Bratislava: SúV ČZTV.

Heinicke, K., Heinicke, I. Schmidt, W. \& Wolfarth, B. (2005). A three-week traditional altitude training increase hemoglobin mass and red cell volume in elite biathlon athletes. Int J Sports Med, 26 (5) 350-355.

Hendl, J. (2004). Prehled statistických metod zpracování dat, analýza a metaanalýza dat. Praha: Portál.

Hochachka, P. W. et al. (1999). Adaptation and conservation of physiological systems in the evolution of human hypoxia tolerance. Comparative Biochemistry and Physiology Part A: Molecular Integrative Physiology 124, 1-17.

Chapman, R. F., Gundersen, J. S. \& Levine, B. D. (1998). Individual variation in response to altitude training. J Apply Physiol, $85,1448-1456$.

Jokl, E. (1968). Medicine and Sport: Exercise and Altitude. Basel: S. Karger AG.

Levine, B. D. \& Gundersen, J. S. (1997). Living high-training low: effect of moderate-altitude acclimatization with low-altitude training on performance. J Appl Physiol, 83, 102-112.

Mader, A. \& Hollmannn, W. (1977). Zur Bedeutung der Stoffwechselleistungsfähigkeit des Eliteruderers im Training und Wettkampf. Leistungssport (Beiheft p): Ausdauertraining-Stoffwechsellgrundlagen und Steuerungsansätze, 9, 7-63.

Neumann, G., Pfützner, A. \& Berbalk, S.(1998). Optimiertes Ausdauertraining. Aachen: Meyer \& Meyer Verlag.

Pupiš, M. \& Korčok, P. (2007). Hypoxia ako súčast' športovej prípravy. Banská Bystrica: Univerzita Mateja Bela FHV.

Ratz, I. K., Coggan, A. R. \& Mcgregor, S. J. (2009). Seven days of live-high/train-low exposure does not change important physiological or performance factors. ASCM 56th Annual Meeting, Seattle, Presentation number 739.

Rusko, H. K., Tikkanen, H. O. \& Peltonen, J. E. (2004). Altitude and endurance training. Journal of Sports Sciences 22 (10), 928-944.

Saltin, B., Larsen, H., Terrados, N., Bangsbo, J., Bak, T., Kim, C. K., Svedenhag, J. \& Rolf, C. J. (1995). Aerobic exercise capacity at sea level and altitude in Kenyan boys, junior and senior runners compared with Scandinavian runners. Scandinavian Journal of Medicine \& Science in Sports, 5 (4), 209-221.

Saunders, P. U., Pyne, D. B. \& Gore, CH. J. (2009). Endurance Training at Altitude. High Altitude \& Biology 10 (2).

Suchý, J. (2012). Využití hypoxie a hyperoxie ve sportovním tréninku. Praha, Karolinum.

Suchý, J., Dovalil, J. \& Perič, T. (2009). Současné trendy tréninku ve vyšší nadmořské výšce. Česká kinantropologie 13 (2), $38-53$.

Svedenhag, J., Saltin, B., Johansson, C. \& Kaijser,L. (1991). Aerobic and anaerobic exercise capacities of elite middle-distance runners after two weeks of training at moderate altitude. Scandinavian Journal of Medicine \&Science in Sports 1 (4), 205-214.

Vaněk, M. (1968). Vliv nadmořské výšky Mexico City na psychickou složku sportovní výkonnosti. Teor. Praxe Těl. Vých., 16, 401-408. 